\title{
Experimentação em Design e Arte: Van Gogh, ponte entre a teoria da cor e a escala de ampliação
}

\author{
Experimentation in Design and Art: Van Gogh, bridge between the theory of color and \\ scale-up
}

Marko Alexandre Lisboa dos Santosi, Alexia Luanda Teske da Cruzii, Bruna Inez Perini ${ }^{\mathrm{iii}}$

\begin{abstract}
Resumo
Este artigo relata a experiência de um trabalho coletivo realizado pelos alunos da primeira fase de um curso de Design. Por meio deste estudo objetivou-se a compreensão da importância da arte moderna no contexto do pós-impressionismo, além de conceitos acerca da Teoria da Cor e da Escala de Ampliação de Formas como contribuições para uma formação em Design mais significativa pelos acadêmicos do curso.
\end{abstract}

Palavras-chave: design, pós-impressionismo, teoria da cor, escala.

\section{Abstract}

This article reports on the experience of a collective work developed by first-phase Design students. By means of this study, we aim at understanding the importance of Modern Art in the context of Post Impressionism, as well as concepts about the Color Theory and Scale-up as contributions to a more meaningful Design education.

Keywords: design, post impressionism, color theory, scale.

\section{Introdução: a motivação do trabalho}

O presente artigo relata uma iniciativa realizada em um curso de Design, na qual desenvolveu-se um experimento integralizador de assuntos como História da Arte, Teoria da Cor e Escala de Ampliação. Esta proposta foi motivada pela necessidade da correta articulação desses temas que, embora pertencentes a áreas distintas, estão presentes no desenvolvimento de projetos e demais atividades criativas realizadas pelos estudantes de Design.

Neste sentido, o objetivo principal do estudo realizado foi o de elaborar uma atividade que abordasse os três assuntos anteriormente destacados em um exercício prático que se utilizasse de questões teóricas e experimentais apresentadas pelo docente responsável da disciplina e que posteriormente pudessem ser descritos como processo de dinamização desse tipo de conhecimento. Desse modo, para melhor compreender e

Revista Digital do LAV - Santa Maria - vol. 10, n. 1, p. 31 - 53 - jan./abril. 2017 ISSN 1983 - 7348 http://dx.doi.org/10.5902/1983734823918 
desenvolver a atividade então proposta, foram pesquisados estudos semelhantes ao mesmo, conforme apresentado adiante.

Em sua pesquisa, Rossi (2005), desenvolveu uma atividade com a finalidade de conhecer o processo e desenvolvimento da compreensão estética dos alunos. Entre outras questões, a autora defende a introdução da discussão estética em sala de aula, respeitando e valorizando as ideias e teorias intuitivas que os alunos trazem consigo. No estudo é relatada a realização de oitenta sessões da atividade na qual são discutidas a estética de diferentes imagens e obras de arte com os estudantes.

Em cada sessão foram apresentadas aos alunos duas imagens, de modo que estes puderam realizar comparações entre as mesmas. Ainda segundo a descrição feita por Rossi (2005), estes estudos de leitura estética visual permitem que os estudantes tenham uma percepção visual mais sofisticada e passem a compreender a arte de maneira mais significativa para suas vidas.

Já Schultz (2011), acredita que a disseminação de estudos sobre a prática da realização de releituras de pinturas apresenta, no mínimo, dois aspectos positivos: o de incentivar o desenvolvimento da sensibilidade artística, além de permitir que o estudante compreenda os aspectos técnicos, bem como os processos de criação da arte.

Em seu estudo, Santos et. al. (2012), afirma que a leitura de imagem desempenha um grande papel dentro das salas de aula de artes. O autor denomina esta prática de "releitura da obra de arte" onde, por meio da interpretação, o aluno passa a compreender os movimentos artísticos envolvidos no processo, além de desenvolver a releitura dessas pinturas de acordo com seu modo de observá-las.

Segundo Oliveira apud Santos et. al. (2012), para leitura de uma imagem deve-se estar atento às técnicas, às cores utilizadas, às texturas, à forma, à harmonia, ao contraste, à luminosidade, às dimensões e às proporções, de modo que o conjunto dos elementos seja determinante para a compreensão das motivações estéticas de cada um dos movimentos artísticos estudados.

A partir do levantamento de pesquisas correlatas a esta, foi perceptível a importância da atividade que seria então desenvolvida. Por meio desse levantamento bibliográfico, foram extraídos alguns temas e tópicos de importância a serem abordados na atividade a ser realizada, são eles:

a) Contextualização do movimento artístico e apresentação da vida e obras do artista abordado;

b) A execução da técnica de releitura por meio de desenhos e pinturas;

c) Compreensão da técnica de pintura utilizada pelo artista por parte dos estudantes;

Revista Digital do LAV - Santa Maria - vol. 10, n. 1, p. 31 - 53 - jan./abril. 2017 ISSN 1983 - 7348 http://dx.doi.org/10.5902/1983734823918 
d) Incentivo por parte do professor para que a particularidade do traço e a sensibilidade estética de cada estudante seja privilegiada de modo que a fidelidade e semelhança entre a obra de referência e a releitura teria menor importância nesta atividade.

A partir da apresentação desse panorama geral, a seguir está apresentado o referencial teórico necessário à compreensão da atividade assim como o detalhamento de cada uma das etapas empregadas no trabalho.

\section{Referencial teórico}

Para melhor compreender o processo de desenvolvimento dessa atividade, se faz necessário abordar contextualmente os temas abordados na mesma, à maneira que foram apresentados aos estudantes participantes da atividade.

\subsection{O contexto da obra de Vincent Van Gogh}

Vincent van Gogh nasceu em uma comunidade rural no sul da Holanda em 30 de março de 1853. Essa foi uma fase de mudanças sociais significativas em todo o planeta. A França passava por um período conhecido como Belle Époque, caracterizado pelo desenvolvimento cultural e industrial (FELL, 2007). Vincent é filho do pastor Theodorus van Gogh e de sua esposa Ana Carbentus. Sua família, de classe média, era religiosa e composta de seis filhos, entre eles, Theo, que posteriormente exerceria grande influência sobre a vida do artista.

Aos 27 anos, após crises emocionais e uma juventude conturbada, Van Gogh decide experimentar a carreira artística e passa a frequentar aulas convencionais de arte. Nesse período, o último andar da casa de sua família em Nuene, cidade ao sul da Holanda, transformou-se em um estúdio de pintura. Esse local proporcionava ao artista uma linda vista de onde ele pode imortalizar o jardim de um presbitério próximo, utilizando as cores das quatro estações.

Desde o início, Vincent era sensibilizado pelas nuances: a tristeza do inverno era representada por imagens sombrias e o outono era pintado em tons de marrom. Ele também pintava artefatos encontrados em seu quintal, como cestos de maçãs, réstias de cebola e batatas recém-arrancadas da terra, como é possível observar na obra Still Life with Cabbage and Clogs de 1881 (figura 01).

Revista Digital do LAV - Santa Maria - vol. 10, n. 1, p. 31 - 53 - jan./abril. 2017 ISSN 1983 - 7348 http://dx.doi.org/10.5902/1983734823918 


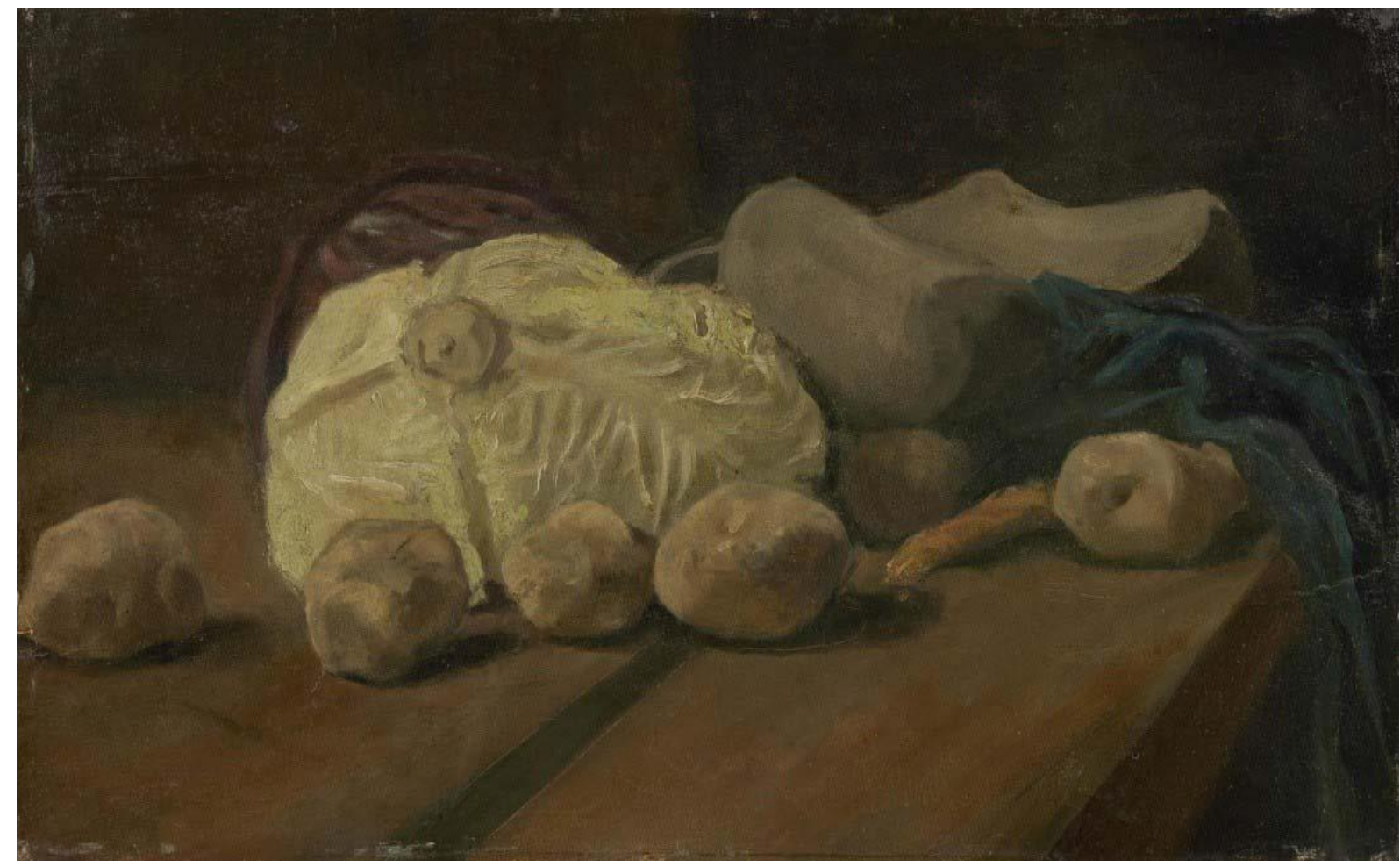

Figura.01 - Still Life with Cabbage and Clogs, óleo sobre tela, $34 \mathrm{~cm}$ x $55 \mathrm{~cm}$, Vincent van Gogh, 1881

Fonte: Van Gogh Museum, Amsterdam (Vincent van Gogh Foundation). Acesso em 28 jun 2016.

Com o objetivo de produzir e comercializar seus quadros, Vincent recorreu a ajuda financeira de seu irmão, Theodorus e em troca passou a possuir os direitos sobre suas pinturas, além de responsabilizar-se pela venda das mesmas.

Após o falecimento de seu pai, Vincent deixa a casa de sua família e passa a viver próximo ao presbitério de Nuenen. Neste período, ele estabelece contato com tecelões e passa a admirar os processos realizados por eles diante dos teares. Durante sua observação, o artista se surpreende pela maneira como os tecelões entreteciam as cores para criar padrões de estampados e xadrezes o que o levou a formular novas ideias sobre a associação de cores para obtenção de tons.

O conhecimento elevado da cor forneceu a Van Gogh o instrumental forjador de sua genialidade. Cerca de um ano antes da eclosão do sublime colorido de sua pintura, ele escreveu uma carta para o irmão Theo, onde faz um pedido:

(...) Se encontrares algum livro sobre essas questões da cor, um livro que seja bom, evie-me-o antes de qualquer outra coisa, pois é

Revista Digital do LAV - Santa Maria - vol. 10, n. 1, p. 31 - 53 - jan./abril. 2017 ISSN 1983 - 7348 http://dx.doi.org/10.5902/1983734823918 
necessário que eu saiba tudo sobre isso. Não se passa um dia sem que eu procure me instruir (PEDROSA, 2004, p. 17).

Michel-Eugène Chevreul, químico parisiense, publicou o primeiro círculo cromático do mundo em 1839, mostrando a relação científica entre as cores. O químico dividiu o círculo em cores quentes e cores frias e ainda explicou que as cores opostas no círculo formavam os melhores contrastes. Este estudo influenciou de maneira positiva os estudos de Vincent, que foi além e formulou combinações nada óbvias a partir do estudo do círculo cromático - por exemplo, preto e branco, preto e laranja, preto e dourado, prata e vermelho. Além disso, associou determinadas combinações com as estações: preto e branco para silhuetas de galhos sobre campos nevados, rosa e verde para flores de jardim e brotos primaveris, laranja e azul para trigais maduros e céus azulados de verão (FELL, 2007).

O artista também descreveu minuciosamente para o irmão suas regras de cores:

Os antigos só admitiam três cores primárias: amarelo, vermelho e azul, e os pintores modernos não admitem nenhuma outra. De fato, essas três cores são as únicas insolúveis e irredutíveis. Todos sabem que a luz solar é composta por uma série de sete cores, que Sir Isaac Newton chamava de primitivas [...], mas é óbvio que a denominação primitiva não pode ser aplicada a três delas, que são compostas, pois o laranja é a uma mistura de vermelho e amarelo; [...] Assim, de acordo com os antigos, é preciso reconhecer que existem apenas três cores verdadeiramente elementares na natureza, as quais, quando misturadas em dupla, produzem mais três compostas, ditas secundárias: laranja, verde e violeta. Esses rudimentos aperfeiçoados pelos cientistas modernos, levaram a elaboração de certas leis que formam uma teoria esclarecedora das cores [...]. (FELL, 2007, p. 73).

Os meses que se sucedem resultam em arrebatadoras investidas nos domínios da cor e no deslocamento de Vincent para a Antuérpia no ano de 1985. Após estudar por seis semanas na academia de Antuérpia, mudou-se para Paris em 1886, para ter aulas de arte no ateliê de Fernand Cormon. Ali, conheceu pintores vanguardistas. Em carta ao irmão escreveu:

Revista Digital do LAV - Santa Maria - vol. 10, n. 1, p. 31 - 53 - jan./abril. 2017 ISSN 1983 - 7348 http://dx.doi.org/10.5902/1983734823918 
Em Antuérpia eu nem sabia quem eram os tais impressionistas; agora os vi em pessoa e, apesar de não pertencer ainda ao clube, admirei algumas de suas pinturas: um nu de Degas, uma paisagem de Claude Monet (FELL, 2007, p.79).

O impressionismo foi um movimento artístico que definia em suas pinturas a forma por meio da utilização das variações da luz refletida e rebelou-se contra a crença de que um quadro devia ser avaliado pela fidelidade ao objeto retratado. Os artistas impressionistas evitavam formas exatas e utilizavam tinta a óleo com pinceladas rápidas e curtas. As cores utilizadas eram geralmente complementares em justaposição, o que resultava em imagens brilhantes e atmosféricas, que transferiam seus sentimentos para as obras. Muitos artistas enxergaram o estilo como o último estágio da expressão artística. Van Gogh, apesar de engajar-se no movimento, o considerava apenas mais um passo para formas de expressão ainda mais estimulantes.

Em Paris, Van Gogh inspirou-se em vistas da cidade (figura 02), naturezas mortas e autorretratos.

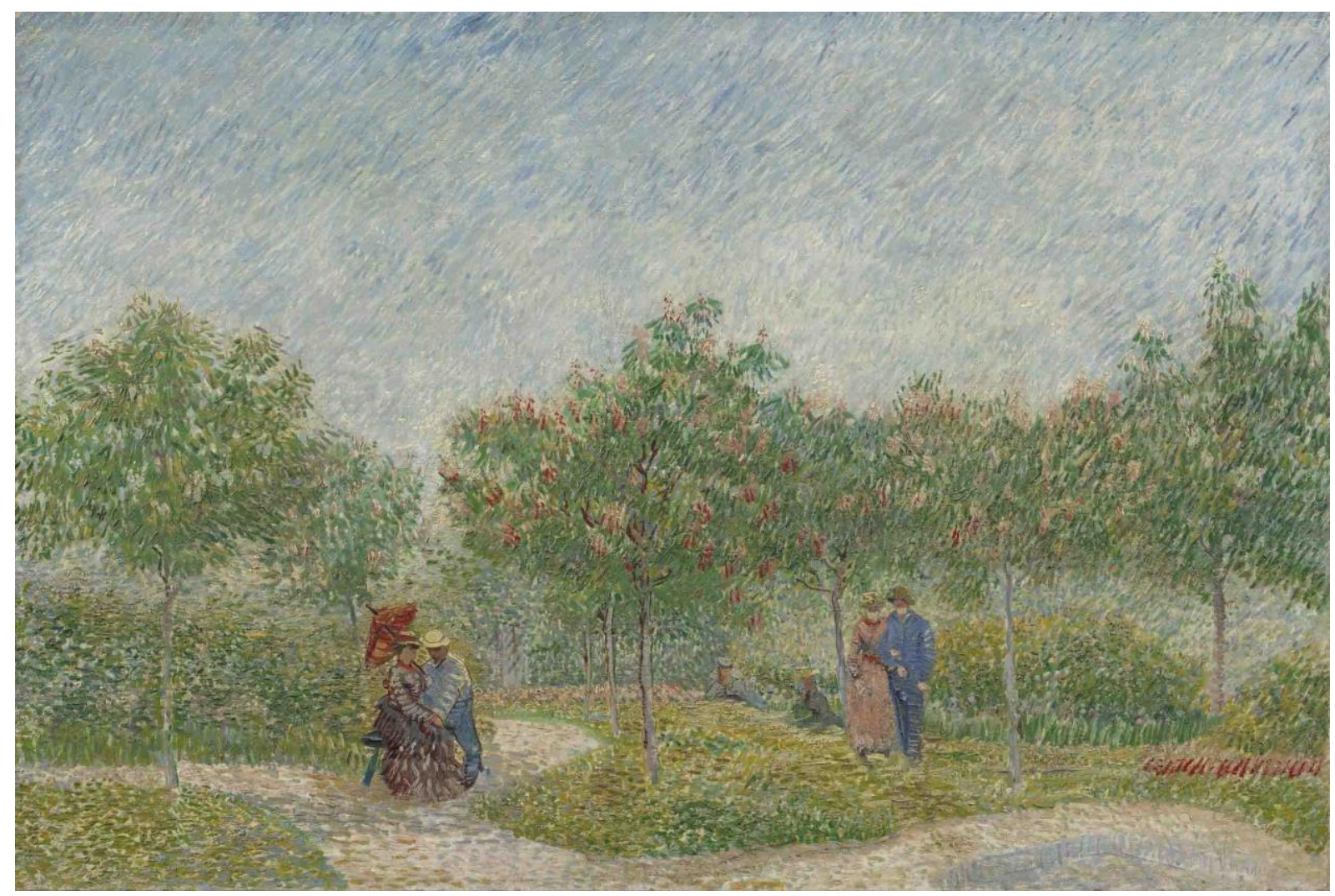

Figura.02 - Garden with Courting Couples: Square Saint-Pierre, óleo sobre tela, $75 \mathrm{~cm} \times 113 \mathrm{~cm}$, Vincent van Gogh, 1887. 
Fonte: Van Gogh Museum, Amsterdam (Vincent van Gogh Foundation). Acesso em 28 jun 2016.

Em 1888, Vincent decidiu que se mudaria para Arles, no sul da França, em busca de paisagens coloridas e da esperança de recuperar sua saúde, que havia sido prejudicada pelo tempo em que viveu na cidade. Em Arles, o pintor começou a pôr em prática seu plano de criar uma colônia de artistas e alugou alguns quartos na casa da Place Lamartine que ficou conhecida como a "Casa Amarela". Van Gogh convidou alguns de seus amigos, pioneiros vanguardistas, para fazerem parte desta sua colônia idealista.

Paul Gauguin foi seu primeiro convidado. Sua chegada causou um grande alvoroço na vida de Van Gogh. Com o intuito de agradar o amigo, Vincent produziu obras inspiradas no tema girassóis (figura 03) para decorar os aposentos da Casa Amarela e comemorar a chegada de Gauguin. A representação do tema com o fundo amarelo, considerada uma natureza morta, é hoje um dos destaques do Museu Van Gogh.

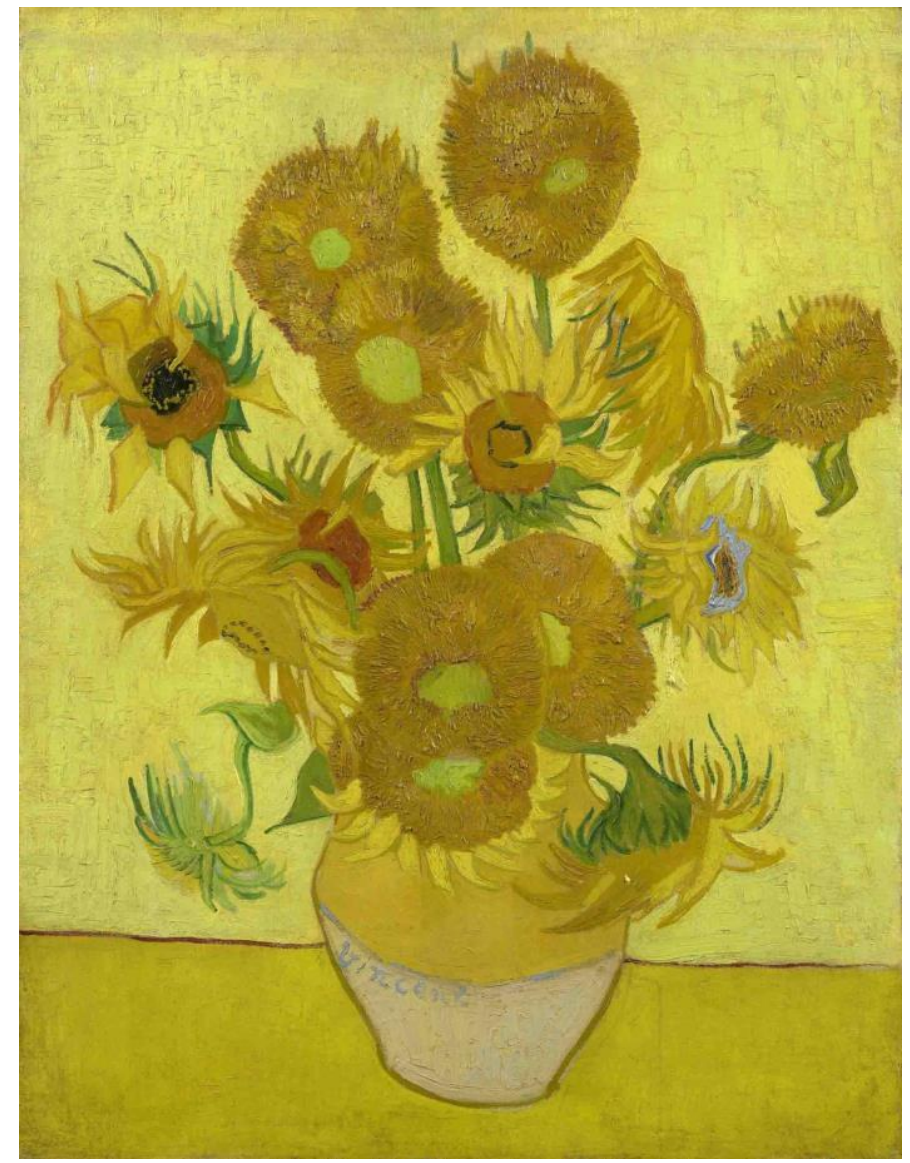

Figura.03: Sunflowers, óleo sobre tela, $95 \mathrm{~cm} \times 73 \mathrm{~cm}$ Vincent van Gogh, 1889.

Fonte: Van Gogh Museum, Amsterdam (Vincent van Gogh Foundation). Acesso em 03 mai 2016.

Revista Digital do LAV - Santa Maria - vol. 10, n. 1, p. 31 - 53 - jan./abril. 2017 ISSN 1983 - 7348 http://dx.doi.org/10.5902/1983734823918 
Embora a colaboração entre Van Gogh e Gauguin tenha sido proveitosa no início, seus temperamentos instáveis causaram conflitos em seu relacionamento, o que culminou em violentas discussões. Em dezembro de 1888, tais conflagrações, resultaram em um colapso mental grave onde, desorientado, Vincent cortou um pedaço de sua orelha esquerda. Desconfia-se que ele sofria de um tipo de epilepsia cujos sintomas eram agravados durante períodos de instabilidade emocional.

Em maio de 1889, o artista deu entrada voluntariamente em um manicômio localizado a apenas 24 quilômetros de Arles e logo voltou a pintar, como forma de terapia. A produção do artista cresceu sobremaneira durante este período. Faz parte desta época a obra $A$ noite estrelada, que retrata a vila de St. Remy debaixo de um céu enluarado e sem nuvens. Ao receber alta do manicômio em maio de 1890, Van Gogh segue o conselho do irmão, mudando-se para o norte da França.

Em seus dois últimos meses de vida, dedicou-se ao desenho e a pintura e produziu quase uma obra por dia. No dia 27 de julho de 1890, em um campo próximo a cidade Auvers, Van Gogh tirou a própria vida com um tiro no peito, vindo a falecer dois dias depois.

\subsection{A Teoria da Cor, a Arte e o Design}

Considerando a notória importância que Van Gogh atribuía aos aspectos cromáticos, sobretudo no que confere ao que hoje se intitula como Teoria da Cor, faz-se necessário abarcar este assunto, ainda que de maneira breve, para que seja possível compreender os motivos que o levaram a se expressar àquela maneira.

Neste sentido, a cor oferece diversas possibilidades de se trabalhar como elemento criativo e plástico para o Artista e para o Designer, afinal é por meio de misturas e combinações que é possível ampliar a expressão gráfica e visual de determinada composição, estendendo assim seus significados.

Barros (2006) acredita que as cores exercem importante influência na formação e na capacidade criativa do sujeito. Para a autora, o ensino do estudo de cor nas escolas e disciplinas é na maioria dos casos uma breve passagem teórica acerca destas questões, o que deveria ser explanado a partir de outra abordagem, ou seja, por meio de cruzamentos entre a teoria e a prática, ambas aplicadas a situações reais na vida do estudante.

Uma das primeiras teorias acerca da cor é iniciada pelo físico Isaac Newton. Para o cientista, a cor é fenômeno puramente físico. De acordo com sua teoria, a luz atinge os objetos e penetra nossos olhos de modo que só as cores provenientes do espectro da luz branca (do sol) poderiam ser consideradas como "cores básicas".

Revista Digital do LAV - Santa Maria - vol. 10, n. 1, p. 31 - 53 - jan./abril. 2017 ISSN 1983 - 7348 http://dx.doi.org/10.5902/1983734823918 
Em 1810 Goethe reformulou a teoria das cores de uma maneira inteiramente nova, sendo o primeiro a ousar confrontar as ideais de Newton sobre luz e cor. Goethe afirma que as sensações de cores em nossa mente são formadas pela nossa percepção, ou seja pela visão. De acordo com o teórico, a maneira como nosso cérebro processa esses dados obtidos pelos olhos, cria um círculo harmônico, onde as cores complementares se localizam em posição oposta no círculo, levando o estudo das cores para campos como o da Fisiologia e da Psicologia.

Muitos artistas se sentiram fascinados pela argumentação de Goethe sobre a cor, sobretudo pela relação entre as cores complementares e a percepção visual. O triângulo de Goethe, no vasto universo da cor, trata-se provavelmente do mais condensado e claro sistema de representação de uma ordem essencial. Muitos teóricos que se dedicaram aos estudos da cor seguiram os passos de Goethe.

Considerada como um divisor de águas quando o assunto é a consolidação do ensino das artes aplicadas, a Bauhaus, modernizou o ensino em torno da Teoria da Cor no contexto do início dos anos 1919, na Alemanha. Seus mestres tiveram liberdade para criar novos métodos didáticos para ministrar suas disciplinas. Josef Albers, em seu livro "A interação da cor" aponta que a cor é o meio mais tocante na arte de modo que se faz necessário um maior aprofundamento sobre estas questões. Além disso, Albers afirma que no contexto da Bauhaus, seria necessário que os estudantes tivessem "um olho sensível à cor", dada a sua importância para as diversas aplicações para as artes, o design e a arquitetura (ALBERS, 2009, p. 88).

Itten e Albers desenvolveram metodologias de ensino, melhorando o processo de assimilação de seus alunos, já Klee e Kandinsky acabaram por desenvolver melhores práticas sobre a composição plástica e seus elementos. Em 1961 Itten publica "A arte da cor" onde fala sobre seus conhecimentos e ensinamentos apontando a necessidade fundamental de se estudar contrastes cromáticos com seus alunos por meio de exercícios práticos com pincel e tinta. Para o artista, a cor tem papel principal e para isso seus alunos devem se familiarizar com a mistura de pigmentos.

Para Itten, a teoria das cores assim como as regras dos contrastes perfaziam aprendizados vitais dos seus ensinamentos. Segundo ele, o aparelho óptico humano não enxerga os pigmentos separadamente, de modo que eles não agem isoladamente a fim de conformar as características cromáticas do que enxergamos - na verdade são os contrastes existentes nas composições cromáticas que, ao chegarem aos nossos olhos, trabalham em conjunto com a nossa percepção.

Tamanha era a importância dada por Johannes Itten às cores que o mesmo dizia que o mais importante era privilegiar a cor como elemento principal de uma composição e que a forma deveria ser ignorada em um primeiro momento; em suas palavras: "Aquele que

Revista Digital do LAV - Santa Maria - vol. 10, n. 1, p. 31 - 53 - jan./abril. 2017 ISSN 1983 - 7348 http://dx.doi.org/10.5902/1983734823918 
primeiro desenha as linhas e depois adiciona cor nunca terá sucesso na produção de um efeito cromático claro e intenso" (ITTEN, 1973, p.20).

Itten considera a elaboração do círculo cromático o ponto de partida para se trabalhar com cor, misturando pigmentos de cores primarias (amarelo, vermelho e azul). Acerca da construção do círculo (figura 04), Barros (2006) destaca:

Itten recomenda um procedimento em etapas para a construção do seu círculo cromático de doze cores, num movimento de dentro para fora. Começa por localizar as cores primarias nos três triângulos centrais, devendo elas preencher também os espaços indicados por seus vértices no perímetro do círculo. As três cores secundárias (laranja, roxo e verde) devem ser obtidas, cada qual, pela mistura de duas primárias, e ocupam os triângulos externos. As terciarias são facilmente obtidas pela mistura das suas vizinhas, complementando os espaços livres no perímetro do círculo. (BARROS, 2006, p. 94)

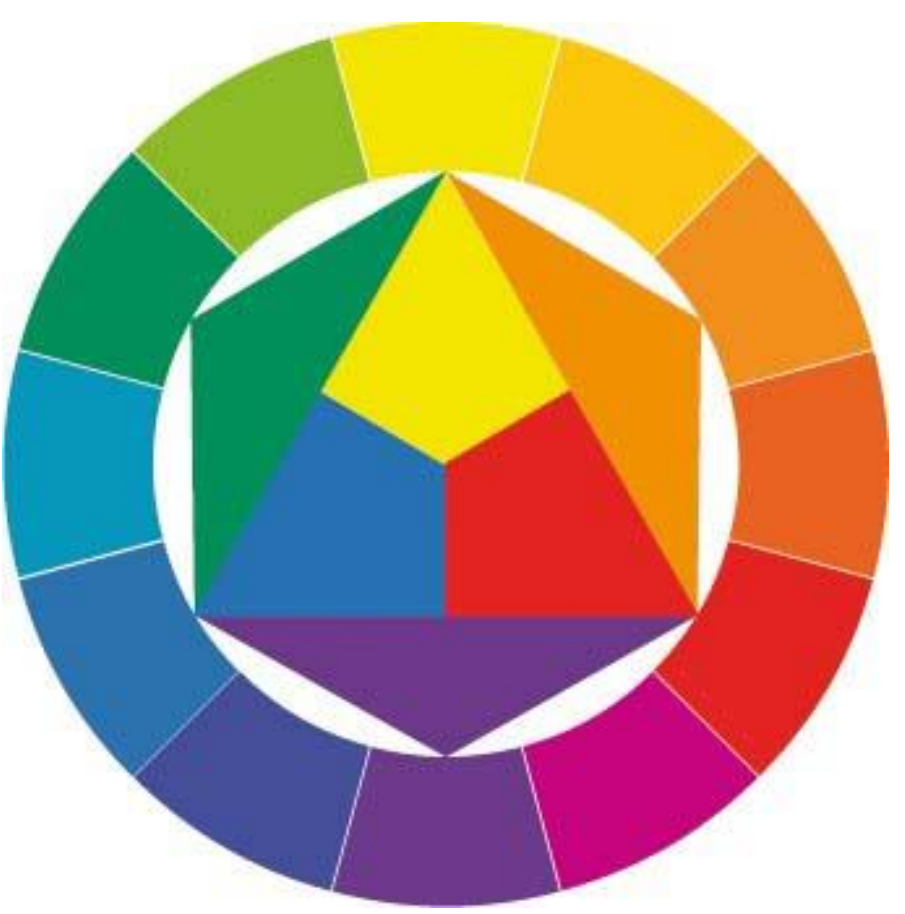

Figura.04: A roda de cores de Johannes Itten

Fonte: Adaptado pelos autores a partir de Barros (2006).

É necessário ressaltar, no entanto, que durante a execução do estudo proposto utilizouse o círculo cromático baseado no processo de impressão offset, onde as cores primárias 
são o Ciano, o Magenta e o Amarelo (Cyan, Magenta, Yellow - CMY). Essa escala de cor se aproxima muito mais do vocabulário cromático que o designer terá ao longo da sua vida profissional. Essa constatação se dá pelo fato de que sistemas de impressão, softwares gráficos, escalas cromáticas e insumos dialogarem entre si com base na escala de cor CMYK. Observe na próxima figura:

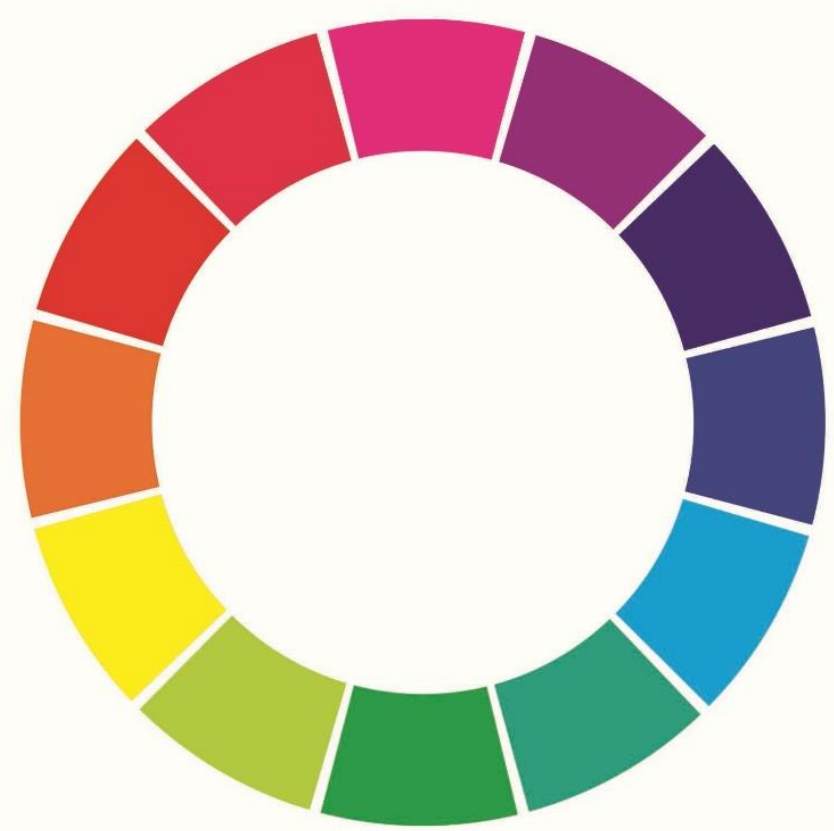

Figura.05: Círculo cromático das cores de processo

Fonte: Dos autores, 2016.

\subsection{Escala: ampliação e redução de formas}

Com intuito de aprimorar os métodos de representação para a comunicação de ideias, diversas técnicas foram desenvolvidas ao longo da história, entre elas, encontra-se o Desenho, que pode ser subdividido em uma série de estilos: o desenho artístico, o desenho técnico, o desenho de observação, o desenho projetivo, entre outros. Entretanto, em algumas situações não é possível reproduzir objetos ou obras em seus tamanhos originais, para isso, segundo Hagio (2014) são adotadas escalas, tanto para a redução quanto para a ampliação de formas.

A definição de escala de acordo com Carranza (2013, p.64) é "a relação de proporcionalidade entre a dimensão do objeto representado e a dimensão do objeto real". Deste modo, ao representar um objeto em suas dimensões reais, diz-se que a produção está na escala 1:1 (um para um) ou natural. Esta, é chamada de escala numérica.

Revista Digital do LAV - Santa Maria - vol. 10, n. 1, p. 31 - 53 - jan./abril. 2017 ISSN 1983 - 7348 http://dx.doi.org/10.5902/1983734823918 
No contexto das representações gráficas, alguns métodos são utilizados para que o redimensionamento de obras de arte e desenhos seja realizado manualmente. Entre eles, encontra-se a quadrícula, que consiste em uma malha retangular, formada por linhas estruturais que cortam um plano de forma horizontal e vertical, criando uniformidade e ritmo na distribuição dos elementos representados. Este recurso, segundo Coelho (2016) pode auxiliar o artista na reprodução de desenhos e estimular o desenvolvimento da organização espacial.

De acordo com Basto (2013) a utilização do método garante a correta transferência das formas e permite manter a proporção dos elementos. Outro ponto destacado pelo autor em seu estudo, é a necessidade de atenção durante a transposição das da cada uma das partes da obra de arte ou do desenho:

A reprodução é garantida, a partir de uma cuidadosa observação, passo a passo, neste caso quadrado a quadrado, possibilitando uma maior aproximação à obra reproduzida. Paralelamente, tornou-se evidente a necessidade da consciência com que devemos perceber o todo e as partes, em sintonia, para não perdermos nunca a ideia do conjunto da obra a reproduzir (BASTO, 2013, p. 29).

Evidentemente, neste texto, os assuntos foram apresentados de maneira resumida. Vale destacar que simultaneamente à disciplina em que foi desenvolvida a atividade, o mesmo grupo de estudantes cursava outras disciplinas que tratavam de temas como a Representação Técnica, o Desenho Manual, além, é claro, da História da Arte.

\section{Desenvolvimento}

O desenvolvimento da dinâmica se deu a partir da apresentação da proposta de atividade aos alunos. O contexto da iniciativa ocorreu em uma aula onde foram abordados os conceitos históricos e estéticos da arte impressionista e pós-impressionista, especialmente daquela desenvolvida por Van Gogh. Assim, foi possível destacar a importância das questões cromáticas existentes nas obras do artista, sobretudo no que concerne à mistura de cores provenientes das cores primárias assim como aos contrastes existentes em suas pinturas.

A atividade contou com a participação de um grupo de estudantes composto por trinta indivíduos que foram divididos em duas equipes de quinze alunos (Grupo A e Grupo B). Ambas equipes foram desafiadas a reproduzir e ampliar uma obra de arte de Van Gogh.

Revista Digital do LAV - Santa Maria - vol. 10, n. 1, p. 31 - 53 - jan./abril. 2017 ISSN 1983 - 7348 http://dx.doi.org/10.5902/1983734823918 
As obras selecionadas para o estudo foram "O campo de trigo com corvos" e a "A noite estrelada" devido as suas pinceladas vivas, vibrantes e cheias de movimento; além, é claro, da significativa importância que essas obras tem no panorama histórico das artes visuais.

A partir disso, foi realizada uma busca imagética nos sites dos museus em que as referidas obras originais encontravam-se expostas. Após salvar os arquivos destas, as mesmas foram inseridas no software Adobe Illustrator. Nesse programa gráfico cada uma das obras foi dividida em partes iguais proporcionais ao formato de papel A3 (42 x 29,7 $\mathrm{cm}$ ). Desse modo, as obras "O Campo de Trigo com Corvos" (figura 06) e "A Noite Estrelada" (figura 07) foram divididas em 20 e 25 partes, respectivamente, a exemplo do método de divisão da quadrícula, entrevisto anteriormente.

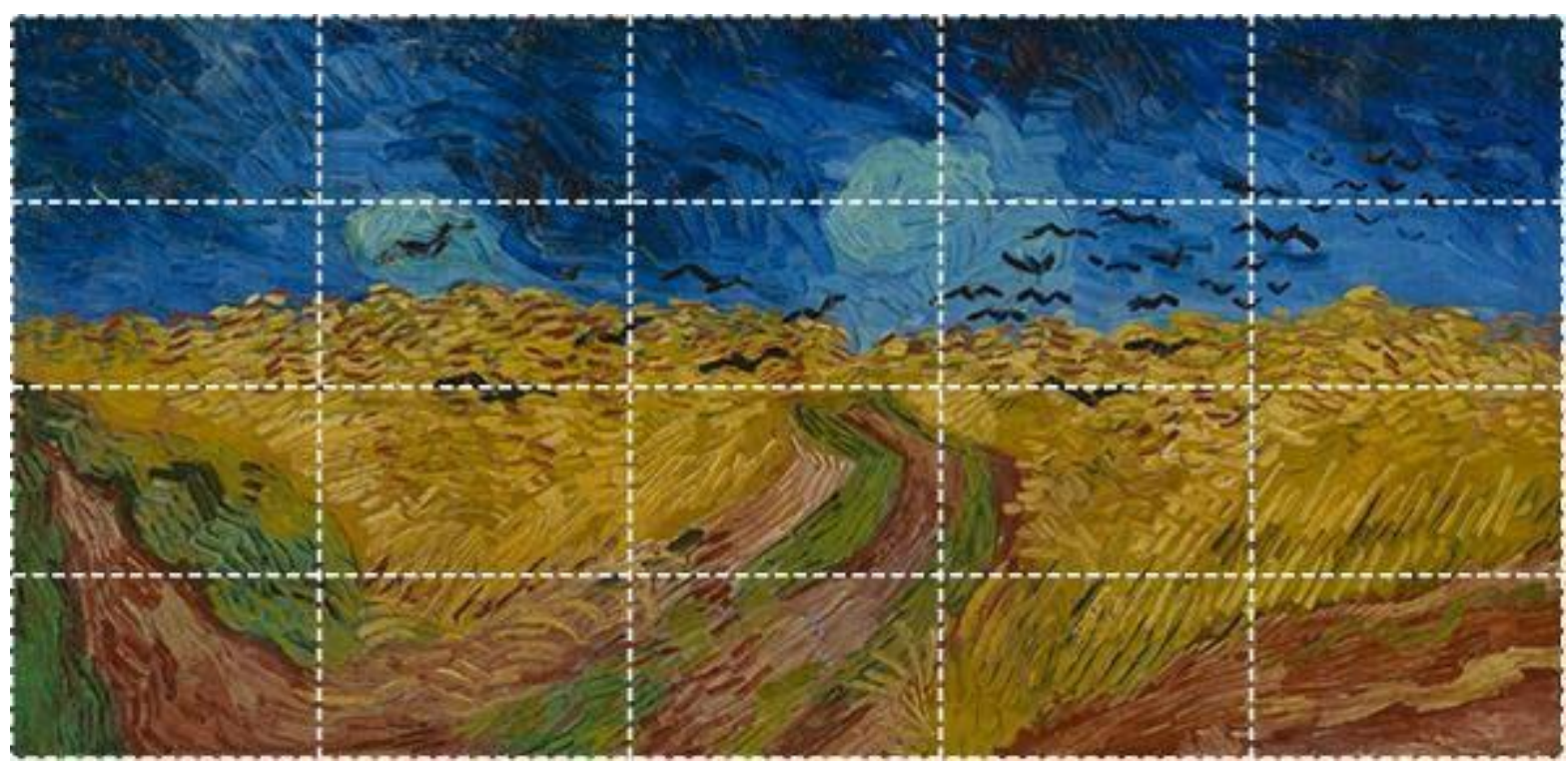

Figura.06: Wheatfield with Crows, óleo sobre tela, $50.5 \mathrm{~cm} \times 103 \mathrm{~cm}$, Vincent van Gogh, 1890

Fonte: Dos autores, baseada na obra encontrada em Van Gogh Museum, Amsterdam (Vincent van Gogh Foundation). Acesso em 26 jan 2016. 


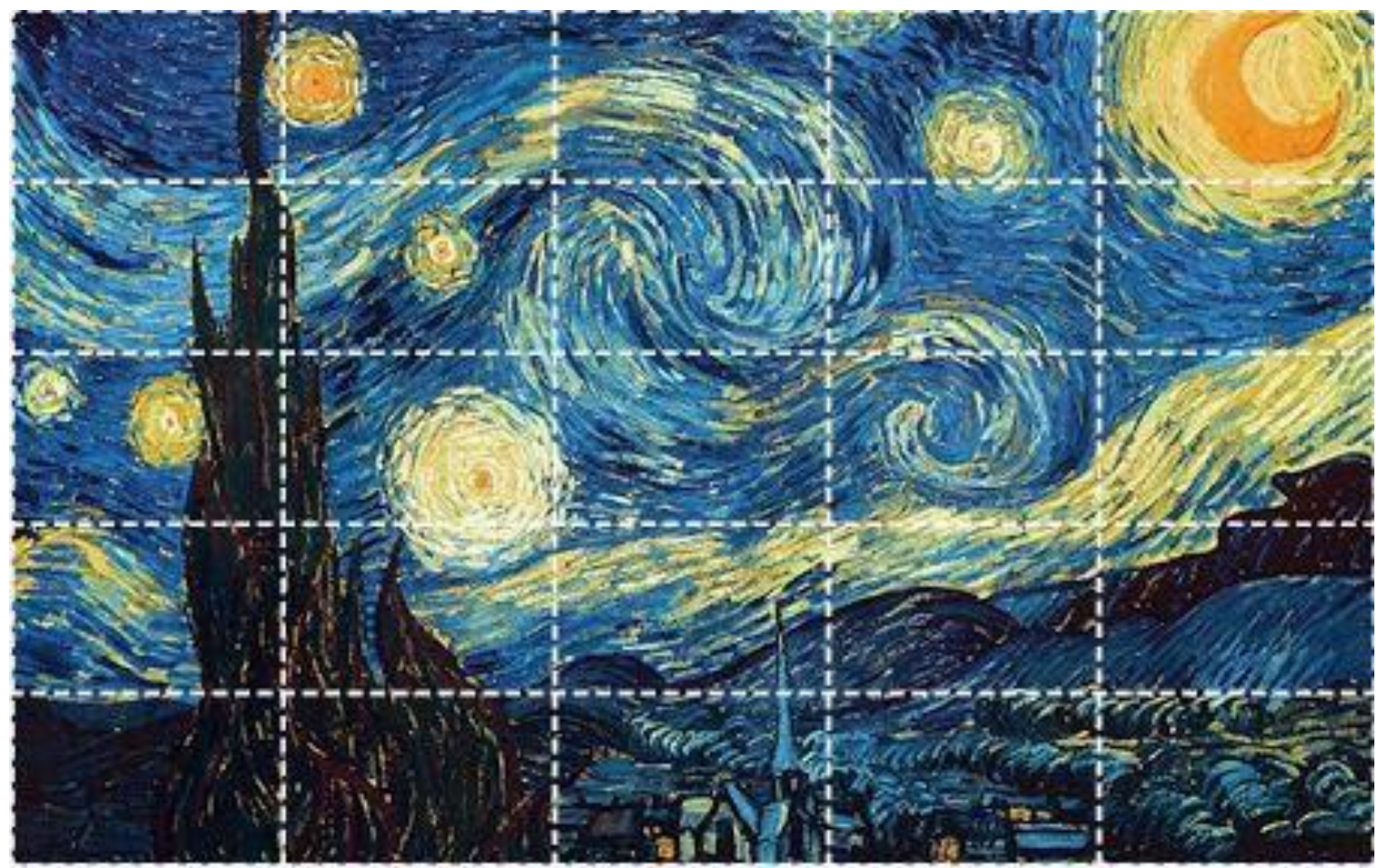

Figura.07: The Starry Night, óleo sobre tela, $73.7 \mathrm{~cm}$ x $92.1 \mathrm{~cm}$, Vincent van Gogh, 1889.

Fonte: Dos autores, baseada na obra encontrada em The Museum of Modern Art, New York. Acesso 26 jan 2016.

Após isso, cada uma das obras quadriculadas foi impressa em duas folhas de papel offset A3 e entregues a cada um dos grupos de estudantes. Neste momento os alunos foram desafiados a reproduzir em uma nova folha de papel A3 cada uma das frações da obra presente naquela impressão. Ao final da atividade a obra deveria ser apresentada ampliada e afixada na parede da sala de aula.

A ampliação foi realizada por meio do desenho a mão livre utilizando os conhecimentos adquiridos acerca do método de quadrícula. Basicamente cada estudante ficou incumbido de ampliar e colorir uma fração da obra. O traçado, maiormente, foi feito a grafite, porém alguns estudantes se valeram da utilização de outros materiais expressivos, como lapiseira, lápis de cor e carvão integral.

Em seguida, munidos de uma tinta específica para o estudo profissional da cor, de pincéis, godês, etc., os estudantes foram incumbidos de preparar as cores que seriam utilizadas na pintura. Para tanto, foi necessário aplicar os conhecimentos adquiridos a partir da Teoria das Cores, mormente no que diz respeito a utilização das cores de processo, tais quais o Ciano, o Magenta e o Amarelo, adicionadas do Branco e do Preto (CMYK).

Revista Digital do LAV - Santa Maria - vol. 10, n. 1, p. 31 - 53 - jan./abril. 2017 ISSN 1983 - 7348 http://dx.doi.org/10.5902/1983734823918 
A próxima figura traz uma sequência de imagens que ilustram o desenvolvimento da atividade. Desse modo, a figura 08a diz respeito ao momento que os estudantes estão preparando as tintas por meio da mistura de cores. É possível perceber que por meio da observação de uma reprodução da obra "A noite estrelada", os alunos se dedicaram a formular diversos tons de azuis. Essas tonalidades são obtidas por meio da mistura das cores primárias Ciano e Magenta, em diferentes proporções. Os azuis mais escuros e profundos são obtidos por meio da adição de tinta preta e os azuis mais claros com a adição da tinta branca.
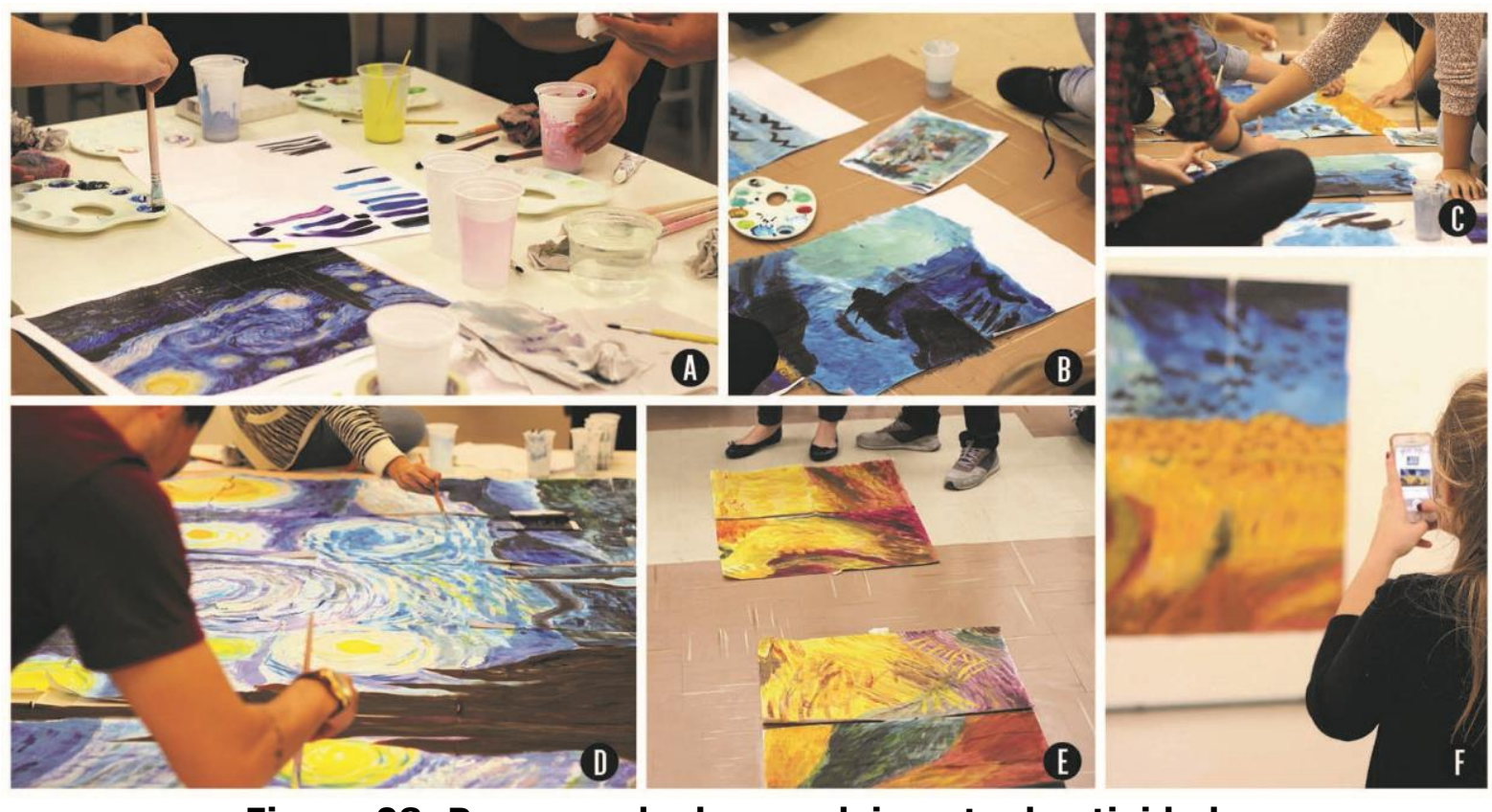

Figura.08: Processo de desenvolvimento da atividade.

Fonte: Dos autores, 2016.

Já as figuras 08 b e 08c demonstram o momento em que os alunos partem da mesa em que estavam preparando as tintas para o chão com o intuito de conectar uma folha a outra para facilitar o encaixe entre cada um dos fragmentos da obra. No detalhe das figuras $08 \mathrm{e}$ e $08 \mathrm{f}$ encontram-se imagens capturadas do grupo que ficou responsável pela ampliação da obra "Campo de trigo com corvos". No detalhe da figura 08f, a estudante fotografando o resultado afixado na parede e compartilhando nas redes sociais.

\section{Resultados e discussão}

Como resultados, foram obtidos dois painéis que são apresentados a seguir:

a) Campo de trigo com corvos (Grupo A - 15 alunos): 
Este painel é constituído de 20 fragmentos reproduzidos a partir da observação de uma miniatura da obra dividida por meio do processo de quadrícula. Para a tela de Van Gogh ficar proporcional ao papel offset $A 3$ foi necessário dividi-la em 20 partes iguais. O grupo composto por 15 estudantes teve um fragmento da obra distribuído para cada integrante de modo que cada um destes foi responsabilizado por representar no mínimo uma das partes da obra. Entretanto, por possuir um número de fragmentos superior ao número de membros da equipe, os alunos com maior agilidade na confecção das suas partes foram encarregados de auxiliar os demais membros e reproduzir mais de um fragmento.

O resultado alcançado pelo Grupo A é apresentado na figura 09. Na fotografia, a ampliação está fixada na parede da sala de aula em que a atividade foi desenvolvida. Destaca-se, neste contexto, a agilidade do grupo que, devido à compreensão da teoria da cor e da mistura de tintas, conseguiu obter a paleta cromática do artista de maneira rápida e relativamente próxima à referência apresentada.

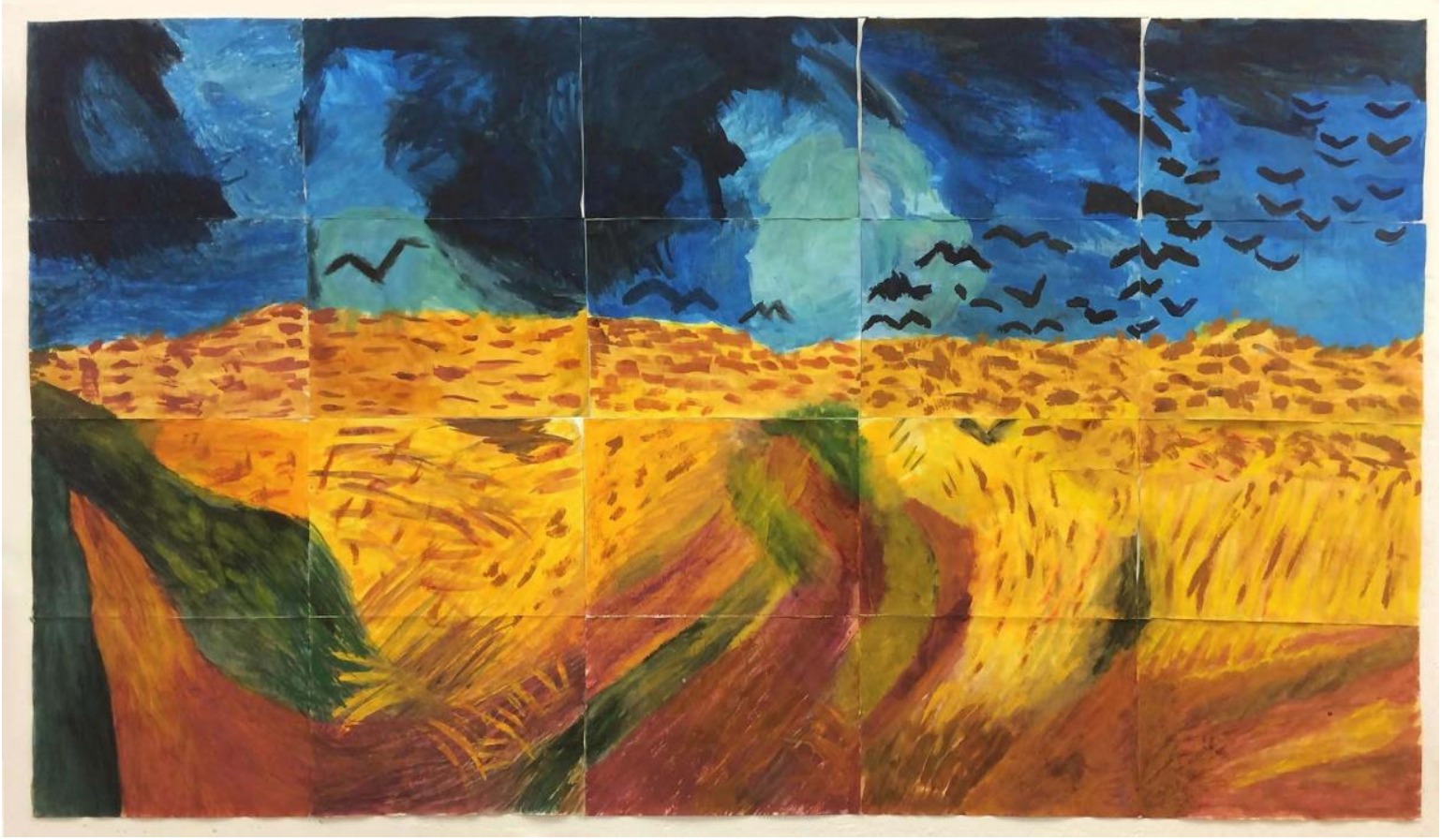

Figura.09: Resultado alcançado pelo grupo $\mathbf{A}$.

Fonte: Dos autores, 2016.

A figura 10 ilustra um fragmento de um dos dois vídeos publicados nas diversas redes sociais do curso de Design em que a atividade foi realizada. Nessa imagem, é possível identificar o tamanho da ampliação que foi realizada a partir do formato $A 3$, neste caso com $210 \mathrm{~cm} \times 118,8 \mathrm{~cm}$ totais (largura $\mathrm{x}$ altura). Evidentemente, para preservar a identidade dos estudantes, as imagens de seus rostos foram distorcidas.

Revista Digital do LAV - Santa Maria - vol. 10, n. 1, p. 31 - 53 - jan./abril. 2017 ISSN 1983 - 7348 http://dx.doi.org/10.5902/1983734823918 


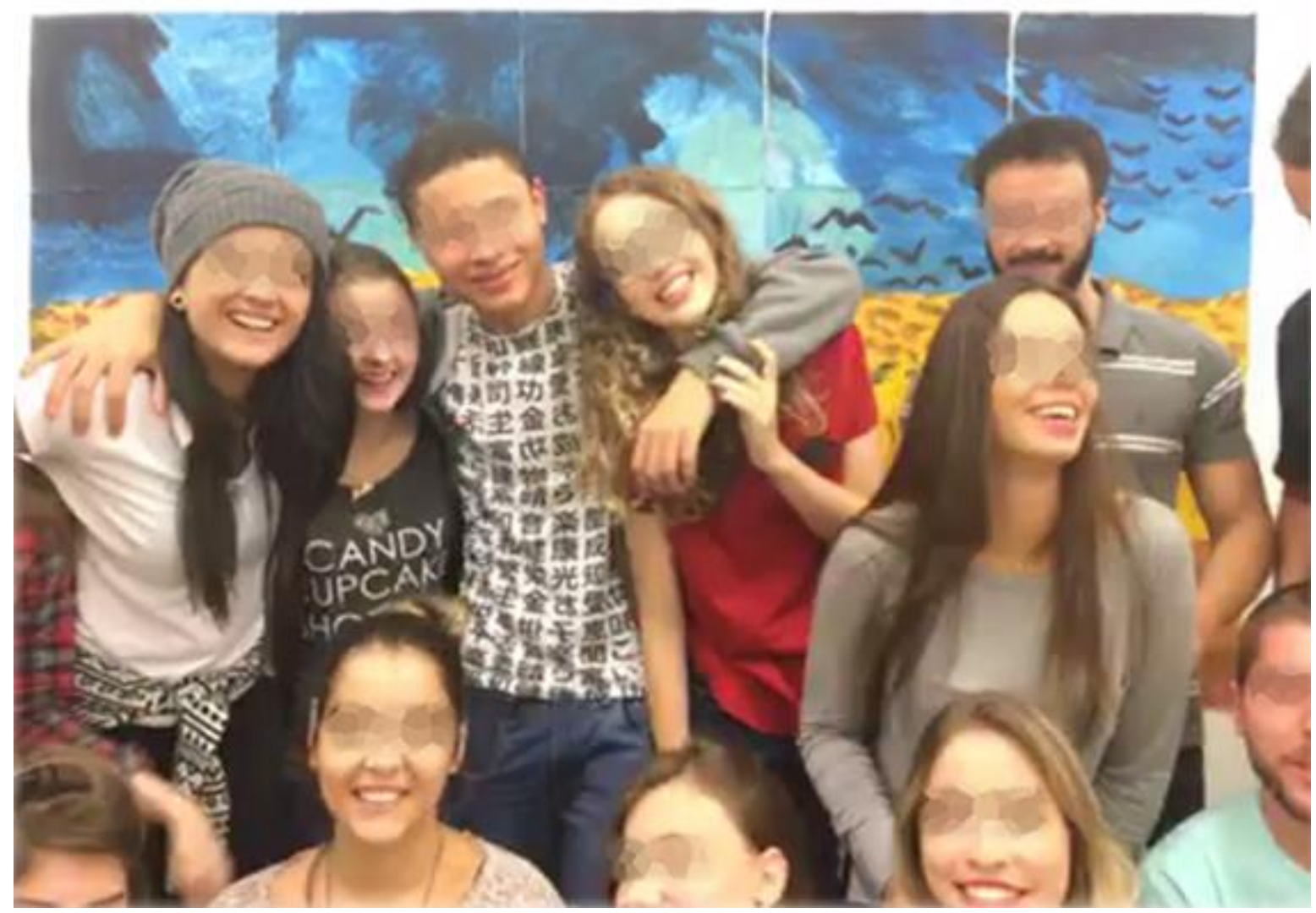

Figura.10: Detalhe do vídeo publicado nas redes sociais do curso de Design.

Fonte: Dos autores, 2016. Disponível em <

https://www.facebook.com/designfurbblumenau/videos>. Acesso em 15 jul 2016.

b) A Noite Estrelada (Grupo B - 15 alunos):

Este painel, assim como planejado no início da atividade, apresenta 25 fragmentos reproduzidos a partir da observação de uma miniatura da obra dividida por meio do processo de quadrícula. Como o grupo de alunos era composto por 15 membros, cada aluno ficou responsável por realizar, obrigatoriamente, no mínimo 1 fragmento. Devido o número de fragmentos ser maior que o de estudantes, foi atribuída a responsabilidade aos alunos com maior agilidade de confeccionar mais de 1 fragmento.

A figura 11 evidencia o resultado final apresentado pelo Grupo B. A fotografia é da parede da sala de aula em que a atividade foi desenvolvida. Destaca-se a representação das pinceladas do artista e a notória aproximação entre as cores do painel reproduzido e da obra de referência.

Vale lembrar que este grupo finalizou seu trabalho após o Grupo A ter concluído. Acredita-se que isso foi ocasionado pela quantidade maior de fragmentos que foram ampliados, neste caso, 20 do Grupo A, contra 25 do Grupo B.

Revista Digital do LAV - Santa Maria - vol. 10, n. 1, p. 31 - 53 - jan./abril. 2017 ISSN 1983 - 7348 http://dx.doi.org/10.5902/1983734823918 


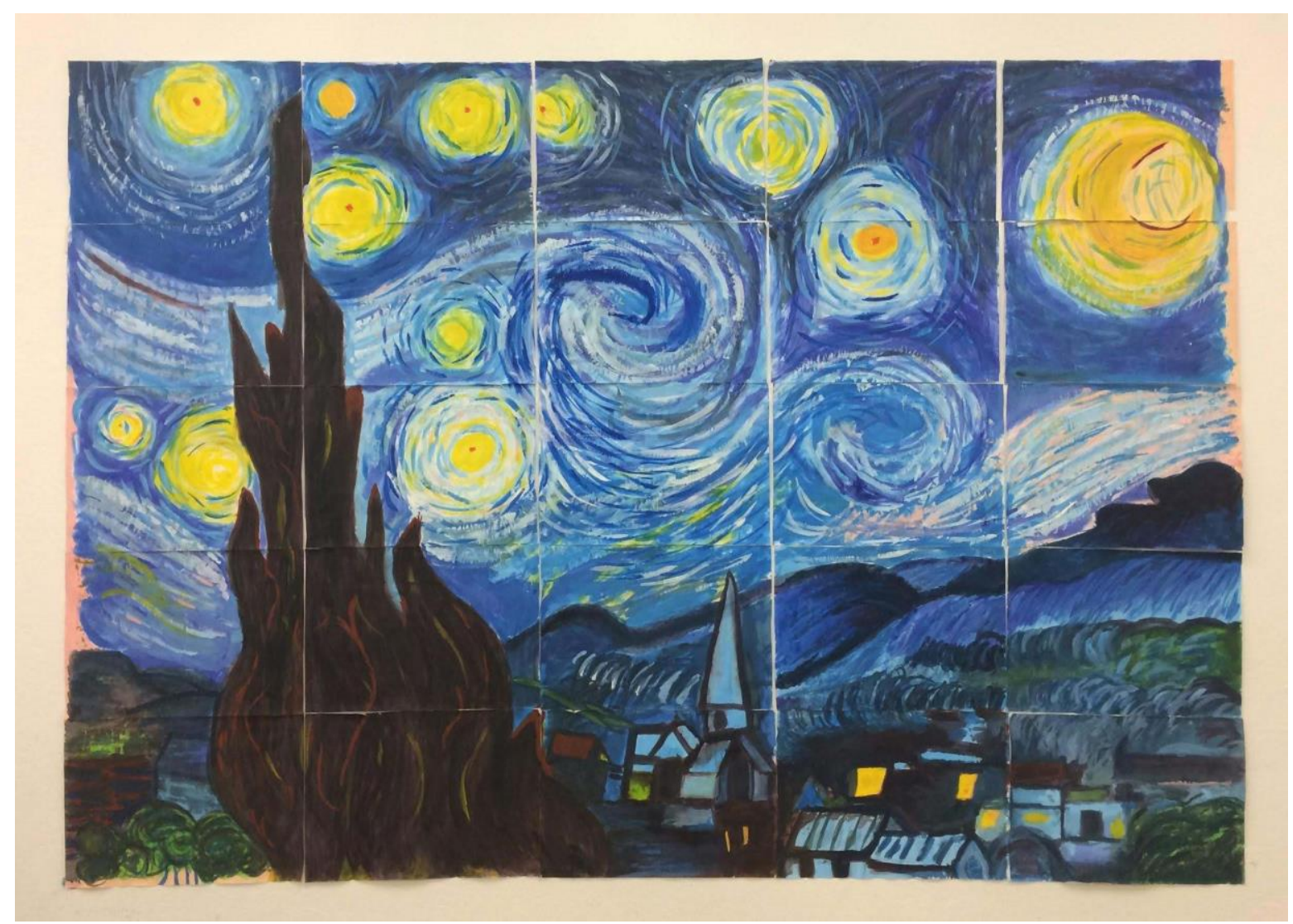

Figura.11: Resultado alcançado pelo grupo B.

Fonte: Dos autores, 2016.

A próxima figura também ilustra um trecho de um dos vídeos publicados nas redes sociais. O tamanho total da ampliação ficou com $210 \mathrm{~cm} \times 148,5 \mathrm{~cm}$ (largura $x$ altura). Evidentemente, para preservar a identidade dos estudantes, as imagens de seus rostos foram distorcidas. 


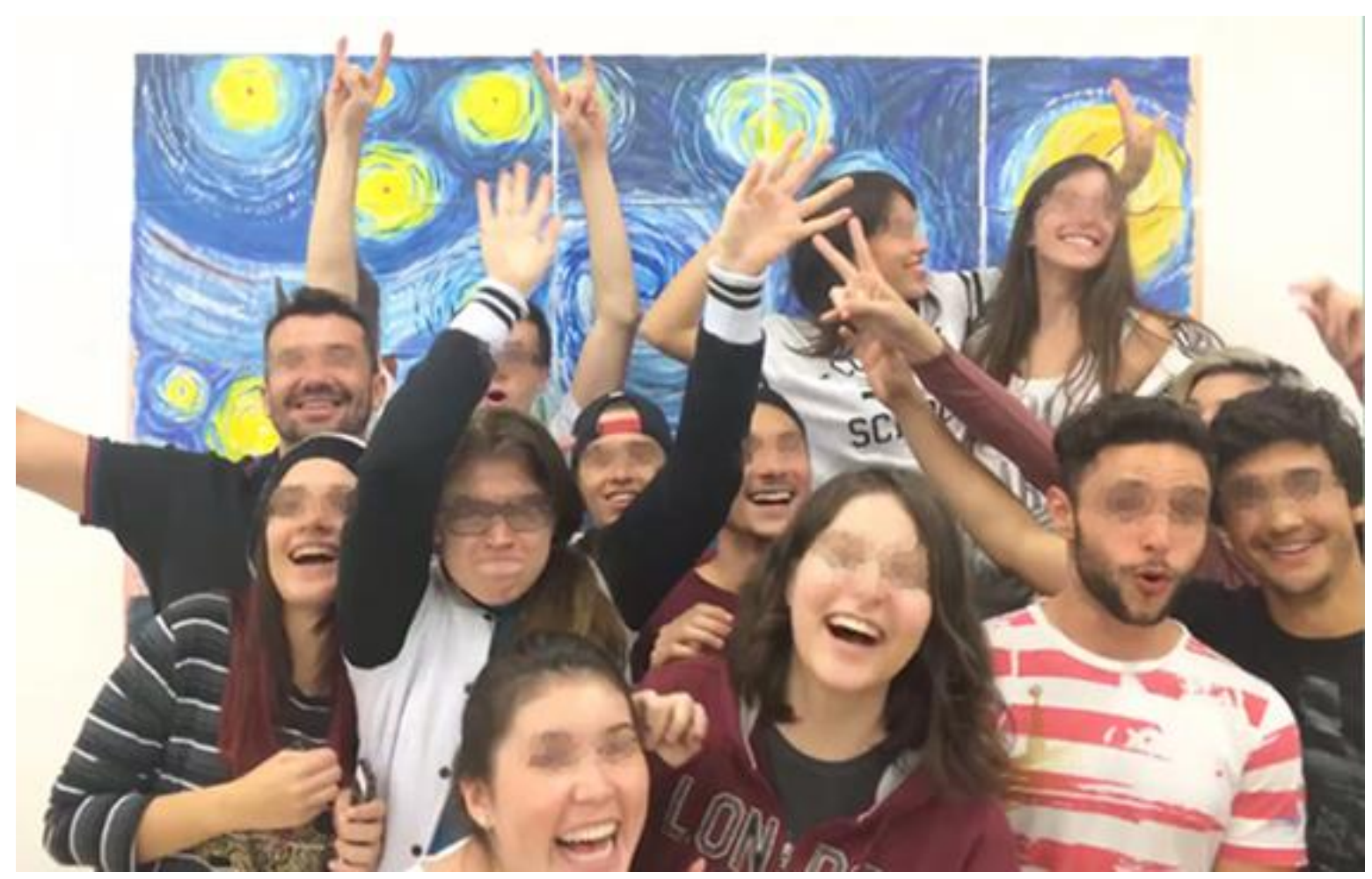

Figura.12: Detalhe do vídeo publicado nas redes sociais do curso de Design.

Fonte: Dos autores, 2016. Disponível em <

https://www.facebook.com/designfurbblumenau/videos>. Acesso em 15 jul 2016.

\section{Considerações finais}

Conforme o observado ao longo do texto, este artigo relata a experiência de uma atividade coletiva realizada em um curso de Design. O método empregado se mostrou pertinente, uma vez que os estudantes obtiveram êxito na conclusão da atividade. Com a utilização do método da quadrícula, utilizado para dividir as obras de referência, foi possível ampliar as imagens sem que as mesmas fossem distorcidas.

Essas observações servem de apoio para formular as principais conclusões deste artigo, que estão apresentadas a seguir:

Foi de suma importância para os estudantes de Design conhecer, compreender e identificar a história de Van Gogh no contexto do Pós-impressionismo. Assim como os demais movimentos modernistas da História da Arte, o Pós-impressionismo confere significativa influência para o Design, sobretudo no que tange às questões acerca da Teoria da Cor e sobre a utilização dos contrastes no desenvolvimento de layouts para o Design Gráfico. Ao se ampliar estas questões para as demais vertentes do Pósimpressionismo, essas influências se tornam ainda mais evidentes, como por exemplo, aquelas verificadas na experiência do Pontilhismo, em que os participantes desse movimento adiantaram aquilo que seria a base da impressão offset.

Revista Digital do LAV - Santa Maria - vol. 10, n. 1, p. 31 - 53 - jan./abril. 2017 ISSN 1983 - 7348 http://dx.doi.org/10.5902/1983734823918 
Por outro lado, a obra de Van Gogh foi determinante para os movimentos artísticos que a sucederam, sobretudo, os movimentos de cunho abstrato-geométricos, dentre os quais: Cubismo, Neoplasticismo, Suprematismo entre outros. Isso se evidencia pelo fato de Van Gogh abandonar o figurativismo lírico expressionista, deixando de representar a realidade dentro de um realismo como entrevisto nas experiências dos grandes mestres (Da Vinci, Rafael, Caravaggio, entre outros).

Essa "estilização" Pós-impressionista viria disseminar uma nova maneira de pensar a representação artística de modo que, se não fosse ela, muito provavelmente os movimentos abstrato-geométricos não teriam se consolidado e muito menos, o Design, como é conhecido, também não.

No que diz respeito à escala de ampliação, o trabalho realizado pelos estudantes foi fundamental para a compreensão de conceitos que serão lembrados ao longo do curso. Tais conceitos são constantemente abordados em disciplinas tais quais Desenho Técnico, Representação Tridimensional, Projeto de Produto, Design Gráfico, entre outras. Não é demais lembrar que os conceitos geométricos são fundamentais para a atuação do Designer, afinal, é dentro dos movimentos artísticos desse cunho que surge o Design.

Outro aspecto relevante a se destacar concerne à Teoria da Cor. Apresentar estes teoremas de maneira prática logo na primeira fase do curso pode proporcionar aos estudantes a garantia de uma graduação muito mais significativa no que diz respeito a esses assuntos. A Teoria da Cor é a base que fundamenta a maior parte dos sistemas de impressão/reprodução da imagem e consequentemente os softwares gráficos e de desenho utilizados pelo Designer também.

Esta empreitada, de certa maneira, já alcançou um de seus principais objetivos: a disseminação do conhecimento. Durante toda a atividade, fotos e vídeos foram gravados de modo que instantaneamente foram parar nas diversas redes sociais. Esse conjunto de imagens resultou em um trabalho de animação no estilo stop-motion realizado pelos próprios estudantes que já alcançou milhares de visualizações nas redes.

Para finalizar, a realização deste trabalho proporcionou para todos os envolvidos, uma experiência significativa e marcante mas, sobretudo, prazerosa; afinal de contas, é sempre um imenso prazer apreciar, discutir, criar e reinventar tendo como inspiração o mestre Van Gogh.

\section{REFERÊNCIAS}

ALBERS, Josef. A interação da cor; tradução Jefferson Luiz Camargo; revisão de tradução Fernando Santos; São Paulo: WMF Martins Fontes, 2009.

BARROS, Lilian Ried Miller. A cor no processo criativo: um estudo sobre a Bauhaus e a teoria de Goethe; São Paulo: Editora Senac São Paulo,2006.

Revista Digital do LAV - Santa Maria - vol. 10, n. 1, p. 31 - 53 - jan./abril. 2017 ISSN 1983 - 7348 http://dx.doi.org/10.5902/1983734823918 
BASTO, Artur Miguel Gama Lima de Sousa. Os desafios da representação gráfica : aspetos teóricos e práticos. 2013. 126 f. Dissertação (Mestrado) - Curso de Artes Visuais, Universidade Católica Portuguesa Centro Regional de Braga, Braga, 2013. Disponível em: <http://repositorio.ucp.pt/handle/10400.14/13749>. Acesso em: 22 ago. 2016.

CARRANZA, Edite G. R. CARRANZA, Ricardo. Escalas de representação em arquitetura. 3 ed. São Paulo: G\&C Arquitetônica, 2013.

COELHO, Marcelo Amaral. REPRODUÇÕES EM MADONNARO: PROPONDO UMA ESTRADA PEDAGÓGICA DE MÃO DUPLA ENTRE O MUSEU E A ESCOLA. Revista Educação, Arte e Inclusão, Florianópolis, v. 12, n. 1, p.6-25, abr. 2016. Disponível em: $<$ http://www.revistas.udesc.br/index.php/arteinclusao/issue/current/showToc>. Acesso em: 22 abril 2016.

FELL, Derek. As mulheres de Van Gogh: seus amores e sua loucura; Derek Fell; tradução Antonio de Padua Danesi. Campinas, SP: Verus Editora, 2007.

HAGIO, Camila Polido Bais. A questão da escala em obras de arte, arquitetura e design. Tese de Doutorado. Universidade de São Paulo, 2014.

ITTEN, Johannes. The art of color: the subjective experience and objective rationale of color, Trad. Ernst van Haagen, New York: Van Nostrand Reinhold Company, 1973.

PEDROSA, Israel. O Universo da Cor. Rio de Janeiro: Editora Senac Nacional, 2004.

VAN GOGH MUSEUM ENTERPRISES B.V (Holanda) (Comp.). Vincent van Gogh. Amsterdã: [s.n], 2011.

ROSSI, Maria Helena Wagner. A estética no ensino das artes visuais. Educação e realidade, v.30,49 - 69 jul. /Dez 2005.

SANTOS, Dalila Cruz; RABELO, Renata Cristina; SYLLA, Aliete Maria Gianelli. A releitura do artista Pablo Picasso aplicada com os alunos do ensino fundamental, 1 ciclo. ColloquiumHumanarum, vol.9, n. Especial, jul-dez, 2012.

SCHULTZ, Valdemar. Leituras e Releituras em Aulas de Artes Visuais Práticas Escolares e Processos de Criação. In: "Subjetividades, utopias e fabulações" Anais do $20^{\circ}$ Encontro da Associação Nacional de Pesquisadores em Artes Plásticas. Rio de Janeiro: ANPAP, 2011.

i Doutor em Design pelo Programa de Pós Graduação em Design da Faculdade de Arquitetura, Artes e Comunicação da UNESP/Bauru. Mestre em Design pelo Programa de Pós-Graduação em Design da FAAC/UNESP em Bauru/SP. Possui Graduação em Desenho Industrial pela UNESP/Bauru. Atua nas áreas de Design de Produto e Design Gráfico com ênfase em projeto gráfico, produção gráfica, representação gráfica, artes visuais, desenho, informática, arquitetura, plástica, meios de expressão e design de moda. Na docência, tem experiência nas disciplinas Desenho Técnico, Auto Cad 2D e 3D, Desenho de Observação, Desenho Técnico Expressivo, Desenho e Ilustração Digital de Moda, Criação de Acessórios, Informatica Aplicada ao Design e à Publicidade, Representação Tridimensional, Meios de Expressão e Projetos de Produto em Design em cursos de graduação em Arquitetura, Publicidade,

Revista Digital do LAV - Santa Maria - vol. 10, n. 1, p. 31 - 53 - jan./abril. 2017 ISSN 1983 - 7348

http://dx.doi.org/10.5902/1983734823918 
Design e Design de Moda de Universidades pública e privadas de Bauru. Atualmente é Professor Efetivo do curso de graduação em Design da FURB em Blumenau/SC.

ii Graduação em andamento em Design. Fundação Universidade Regional de Blumenau, FURB, Brasil.

iii Graduação em andamento em Design. Fundação Universidade Regional de Blumenau, FURB, Brasil.

Enviado em: 9 de outubro de 2016.

Aprovado em: 9 de janeiro de 2017 